\title{
Customers Attitude towards E-Banking System in Rajasthan
}

\author{
Yogesh Kumawat \\ (Research Scholar, Department of Management, Jagannath University, India)
}

\begin{abstract}
Banks have traditionally been in the forefront of harnessing technology to improve their products, services and efficiency. They have, over a long time, been using electronic and telecommunication networks for delivering a wide range of value added products and services. Internet is increasingly used by banks as a channel for receiving instructions and delivering their products and services to their customers. This form of banking is generally referred to as Internet Banking, although the range of products and services offered by different banks vary widely both in their content and sophistication.

Internet banking services are crucial for long-term survival of banks in the world of electronic commerce (Burnham 1996). The market for Internet banking is forecast to grow sharply in the next few years, affecting the competitive advantage enjoyed by traditional branch banks (Duclaux 1996; Liao et al. 1999). Indeed, it also was estimated that financial institutions that failed to respond to the need for Internet banking services would likely lose more than 10\% of their customer base by the year 2000.

Internet banking would help banks present a potentially low cost alternative to brick and mortar branch banking. Banks began to offer Internet banking services, they would still be less costly than the traditional branch banking. This paper presents a study of Customers Behaviour on E-Banking. Paper concludes that what problems consumers are facing while using the e-banking and the opportunities with special reference to Jaipur Rajasthan. The chi-square statistical test has been used to determine the association between customer and awareness and use of e-banking. This research also gives opportunities to conduct the further development in ebanking and helps to the banking professional.
\end{abstract}

Keywords: Attitude, Internet banking, Chi-square test, Customer Behaviour, E-Banking, Perceptions.

\section{Introduction}

Banks have traditionally been in the forefront of harnessing technology to improve their products, services and efficiency. They have, over a long time, been using electronic and telecommunication networks for delivering a wide range of value added products and services. The delivery channels include direct dial - up connections, private networks, public networks etc and the devices include telephone, Personal Computers including the Automated Teller Machines, etc. With the popularity of PCs, easy access to Internet and World Wide Web (WWW), Internet is increasingly used by banks as a channel for receiving instructions and delivering their products and services to their customers. This form of banking is generally referred to as Internet Banking, although the range of products and services offered by different banks vary widely both in their content and sophistication. The levels of banking services offered through INTERNET can be categorized in to three types:

1. The Basic Level Service is the banks' websites which disseminate information on different products and services offered to customers and members of public in general. It may receive and reply to customers' queries through e-mail.

2. In the next level are Simple Transactional Websites which allow customers to submit their instructions, applications for different services, queries on their account balances, etc, but do not permit any fundbased transactions on their accounts,

3. The third level of Internet banking services are offered by Fully Transactional Websites which allow the customers to operate on their accounts for transfer of funds, payment of different bills, subscribing to other products of the bank and to transact purchase and sale of securities, etc. The above forms of Internet banking services are offered by traditional banks, as an additional method of serving the customer or by new banks, who deliver banking services primarily through Internet or other electronic delivery channels as the value added services. Some of these banks are known as 'virtual' banks or 'Internet only' banks and may not have any physical presence in a country despite offering different banking services. 
Chart I: India already has the third-largest Internet user base (120 million) in the world ...

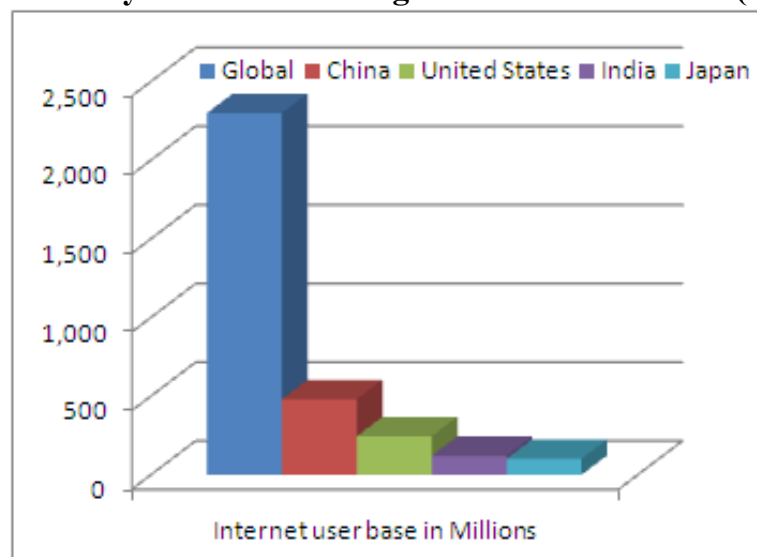

Source: Internet World Stats

Chart II: India's Internet user base is expected to nearly treble 370 million by 2015 through increased mobile penetration

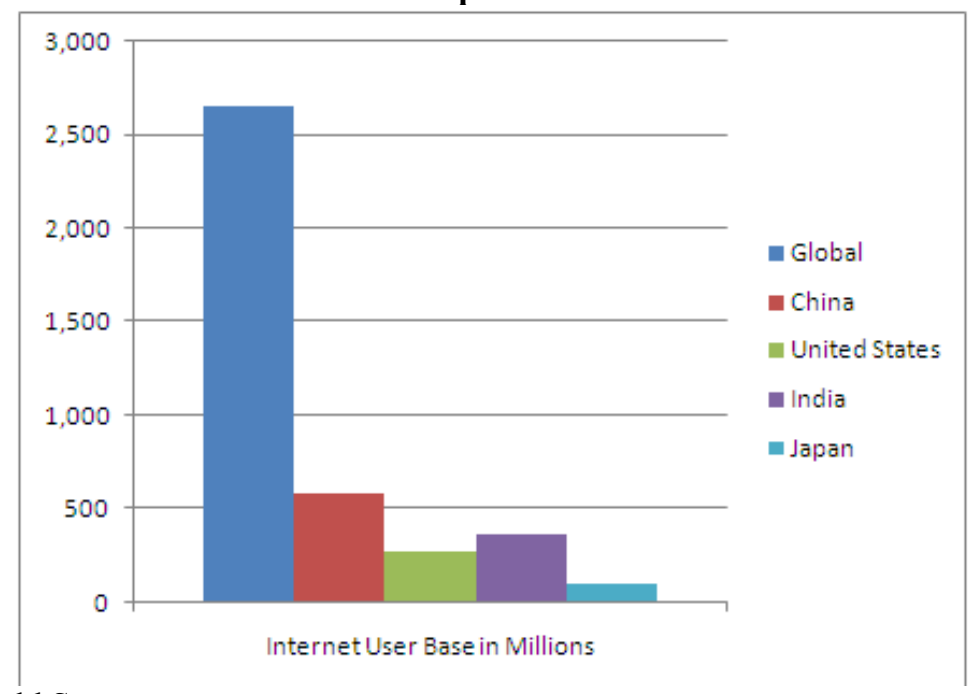

Source: Internet World Stats

Chart III: Growth by (\%) Reach of Online Banking Websites

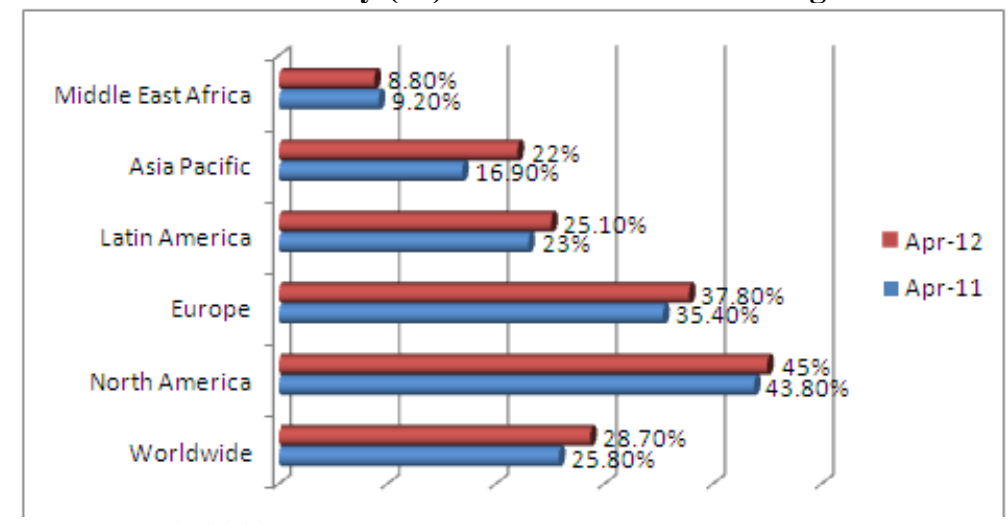

Source: Comscore MMX, April 2012

Globally, 423.5 million people accessed online banking sites during April 2012, reaching 28.7 percent of the internet audience. The global reach of banking sites such as Bank of America grew by 2.9 percentage points over the past year. Over 45 percent of the internet audience in North America accessed bank sites, an increase of 1.2 percentage points, making it the top region for these sites. Europe ranked second by penetration 
(37.8 percent reach) with Latin America (25.1 percent) rounding up the top three. Asia Pacific saw the strongest growth rate of 5.1 percentage points to 22.0 percent of the internet audience accessing bank sites in April 2012. It will be 54 percent till 2014-15.

Internet banking is nothing more than traditional banking services delivered through an electronic communication backbone viz, Internet. But, in the process it has thrown open issues which have ramifications beyond what a new delivery channel would normally envisage and, hence, has compelled regulators world over to take note of this emerging channel. Some of the distinctive features of i-banking are:

1. It removes the traditional geographical barriers as it could reach out to customers of different countries / legal jurisdiction. This has raised the question of jurisdiction of law / supervisory system to which such transactions should be subjected,

2. It has added a new dimension to different kinds of risks traditionally associated with banking, heightening some of them and throwing new risk control challenges,

3. Security of banking transactions, validity of electronic contract, customers' privacy, etc., which have all along been concerns of both bankers and supervisors have assumed different dimensions given that Internet is a public domain, not subject to control by any single authority or group of users,

4. It poses a strategic risk of loss of business to those banks who do not respond in time, to this new technology, being the efficient and cost effective delivery.

\section{Chart IV: Volume wise share of Paper based vs Electronic transactions}

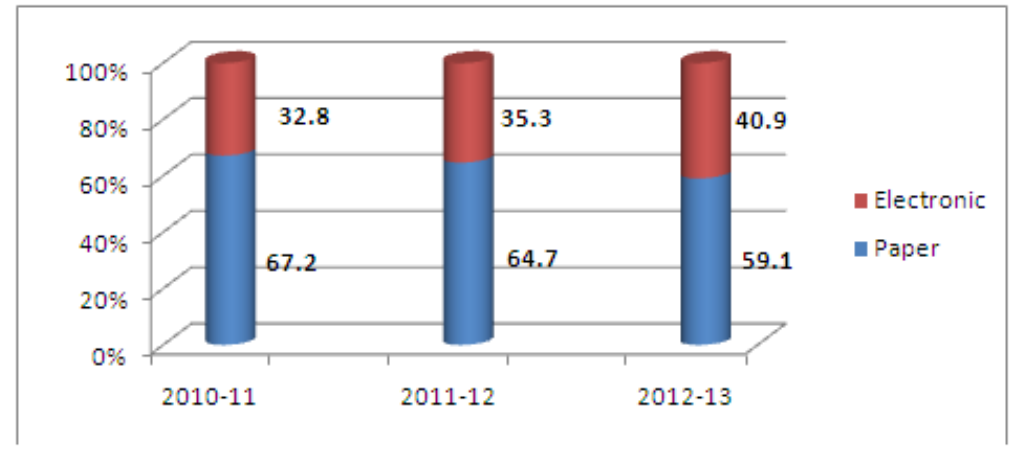

\section{Source: RBI's Reports}

\section{Cost}

The world over, central bankers and regulators have been addressing themselves to meet the new challenges thrown open by this form of banking. Several studies have pointed to the fact that the cost of delivery of banking service through Internet is several times less than the traditional delivery methods. This alone is enough reason for banks to flock to Internet and to deliver more and more of their services through Internet and as soon as possible. Not adopting this new technology in time has the risk of banks getting edged out of competition. In such a scenario, the thrust of regulatory thinking has been to ensure that while the banks remain efficient and cost effective, they must be aware of the risks involved and have proper built-in safeguards, machinery and systems to manage the emerging risks. It is not enough for banks to have systems in place, but the systems must be constantly upgraded to changing and well-tested technologies, which is a much bigger challenge. The other aspect is to provide conducive regulatory environment for orderly growth of such form of banking. Central Banks of many countries have put in place broad regulatory framework for e-banking.

Table 1.1 Internet banking \% of users in various states of India

\begin{tabular}{|l|l|}
\hline State & \%of users banking online \\
\hline Maharastra & 28.7 \\
\hline Delhi & 17.7 \\
\hline Tamilnadu & 10.3 \\
\hline Andra Pradesh & 4.6 \\
\hline Karnataka & 8.3 \\
\hline West Bengal & 4.6 \\
\hline Madhya Pradesh & 3.1 \\
\hline Rajasthan & $\mathbf{3 . 2}$ \\
\hline Gujarat & 3.3 \\
\hline Kerala & 1.8 \\
\hline Haryana & 1.7 \\
\hline Bihar & 1.6 \\
\hline Uttaepradesh & 1 \\
\hline Others & 4.7 \\
\hline
\end{tabular}

Source: Report of internet \& mobile association of India (IAMAI) 
This study attempts to best know the customers attitude towards E-banking and what problems customers are facing with using the e-banking and the opportunities with special reference to Jaipur, Rajasthan under the questions:

1) To know about E-banking system in India

2) To analyze the position of E-banking in India

3) To study the customer awareness and attitude towards E-banking System.

3) To study the risk involved in E-banking system

4) To find out the ways and methods to make E-Banking more advantageous, workable, effective, transparent as well as industrious.

In India, too e-banking has taken roots. A number of banks have set up banking portals allowing their customers to access facilities like obtaining information, querying on their accounts, etc. Soon, still higher level of online services will be made available. Other banks will sooner than later, take to e-banking.

\section{Various methods of e-banking include:}

- Telephone banking

- Online banking

- Short Message Service (SMS) banking

- Mobile banking

- Interactive-TV banking.

\section{Various Services provided by E-Banking}

Customer can Transfer

- Between accounts

- To another account (Digital signature required)

- To credit card

- To another credit card (Digital Signature required)

- To any charity

Customer can Request

- Cheque book

- To change the mailing address

- To inquire or complain,

- To add related account (Power of attorney, parent/child or account with different customer number)

- To manage supplementary cards or add-on cards,

- To dispute credit card,

Customer can View

- Own accounts and related ones

- Credit and Debit cards

- Fund's Time deposit, Savings certificates

- Loans

- Latest transactions of current month

- View, print and save monthly statements (since year 2004)

- To make External transfer (Digital signature required )\& Digital Signature registrations

\section{Benefits of E-Banking}

1. Account Information can be accessed, like balance check and summary of daily transactions.

2. Fund Transfer to the other persons account easily.

3. Request for cheque book, demand draft, stop payment, opening of fixed deposit account, opening of letter of credit etc online.

4. Bank Account statement can be taken online.

5. Online bill payment via E- Banking.

6. Online shopping via e-payments through E-Banking. 


\section{Risks in E-Banking}

There are many types of banks in India, which provide net banking or online banking service to the consumers through Internet. The significant point to be noted with respect to these banks is to make their personal and financial information totally secure so that no unauthorized person or organization should acquire their data to mistreat over the Internet.

1. Optional risk like back door, hijacking sniffing, spoofing to retrieve and use confidential customer information.

2. Reputational risk that is if the services given by banks keep on degrading their standards and status through E-banking mechanism then this reflects upon the overall reputation of the particular bank.

3. Legal risk means the risks as to the unawareness of the local laws and rules of the territories where the banks expend their E-banking network.

4. Business risk-Given the newness of e-banking, nobody knows much about whether e-banking customers will have different characteristics from the traditional banking customers. They may well have different characteristics. This could render existing score card models inappropriate, this resulting in either higher rejection rates or inappropriate pricing to cover the risk. Banks may not be able to assess credit quality at a distance as effectively as they do in face to face circumstances. It could be more difficult to assess the nature and quality of collateral offered at a distance, especially if it is located in an area the bank is unfamiliar with (particularly if this is overseas). Furthermore as it is difficult to predict customer volumes and the stickiness of e-deposits (things which could lead either to rapid flows in or out of the bank) it could be very difficult to manage liquidity.

5. Liquidity risk

6. Market risk

7. Foreign exchange risk.

8. Money laundering.

9. Consumer education and protection.

\section{Research Methodology}

The project studies the customer's attitude towards e-Banking system with special reference to Jaipur, Rajasthan. The 100 respondents were the sample size for the questionnaire. The universe of this research project is Jaipur city.

\section{Hypothesis Testing of Use of E-Banking and Awareness}

John Boyce [2011] uses the chi-square test of independence. In this, while determining whether the number of observations or responses that all into various categories differs from chance. With the help of this technique, we can test whether or not two or more attributes are associated.

Table 2.1: Contingency use of E-Banking and Awareness

\begin{tabular}{|l|l|l|l|}
\hline & Using & Not Using & Total \\
\hline Aware & 57 & 22 & 79 \\
\hline Not Aware & 0 & 21 & 21 \\
\hline Total & 57 & 43 & 100 \\
\hline
\end{tabular}

\section{Hypothesis}

Ho $=$ Use of e-banking and awareness are not related. i.e. people are not aware and not using e-banking service. $\mathrm{Ha}=$ peoples are aware and uses the e-banking services.

\section{Test Statistic:}

$$
\chi^{2}=\sum_{\text {all cells }} \frac{(\text { Observed }- \text { Expected })^{2}}{\text { Expected }}=\sum_{\text {all cells }} \frac{\left(O_{i j}-E_{i j}\right)^{2}}{E_{i j}}
$$

Expected $=\underline{\text { Row Total } \times \text { Column Total }}$

Where

$$
\text { Grand Total }
$$

P-Value from the $\mathrm{x} 2$ - tables with

Degree of freedom $\quad=($ Number of rows -1$) \times($ Number of Columns -1$)$

$$
=(\mathrm{r}-1) \times(\mathrm{c}-1)
$$


Decision Rule: Reject Ho if $p$-value $\leq \alpha$ as usual.

Table 2.2: Calculation of Expected Frequency

On the basis of this hypothesis, the expected frequency corresponding to the no of person aware and using e-banking service would be:

Expected frequencies are calculated using Expected $=($ Column Total $) \times($ Row Total $)$

Grand Total

\begin{tabular}{|l|l|l|l|}
\hline & Using & Not Using & Total \\
\hline Aware & $(57 \times 79) / 100=45.03$ & $(43 \times 79) / 100=33.97$ & $\mathbf{7 9}$ \\
\hline Not Aware & $(57 \times 21) / 100=11.97$ & $(43 \times 21) / 100=9.03$ & $\mathbf{2 1}$ \\
\hline Total & $\mathbf{5 7}$ & $\mathbf{4 3}$ & $\mathbf{1 0 0}$ \\
\hline
\end{tabular}

Table 2.3: Calculation of Chi-Square

\begin{tabular}{|c|c|c|c|c|}
\hline $\begin{array}{c}\text { Observed } \\
\text { Frequency (O) }\end{array}$ & $\begin{array}{c}\text { Expected } \\
\text { Frequency (E) }\end{array}$ & $\mathbf{( O - E )}$ & $\mathbf{( O - E )}^{\mathbf{2}}$ & $\frac{\mathbf{( O - E )}^{\mathbf{2}}}{\mathbf{E}}$ \\
\hline 57 & 45.03 & 11.97 & 143.28 & 3.18 \\
\hline 0 & 11.97 & -11.97 & 143.28 & 11.97 \\
\hline 22 & 33.97 & -11.97 & 143.28 & 4.22 \\
\hline 21 & 9.03 & 11.97 & 143.28 & 15.87 \\
\hline $\mathbf{1 0 0}$ & $\mathbf{1 0 0}$ & $\mathbf{0}$ & - & $\mathcal{X}_{\text {cal }}^{2}=\mathbf{3 5 . 2 4}$ \\
\hline
\end{tabular}

Degrees of freedom $=(r-1)(c-1)=(2-1)(2-1)=1$

The p-value $=P\left(X_{(1)}^{2} \geq X_{\text {cal }}^{2}\right)=P\left(X_{(1)}^{2} \geq 35.24\right)$

It is now necessary to compare this value with the critical values of chi-square. The critical value of chi square with 1 degree of freedom of $5 \%$ level of significance is 3.841 . Since the calculated value is much greater than the critical value of chi-square, the null hypothesis people are not aware and not using e-banking service is rejected. Thus, most of the respondents are aware and using e-banking service.

\section{Major Finidngs}

The research is based on primary data collected through questionnaire. The research is useful to know the consumer attitude towards e-banking system in Jaipur, Rajasthan and the risk involved with e-banking.

The Indian active online audience is reaching the 60 million mark, growing about $30 \%$ annually, of which $25 \%$ are found on online banking-websites. In India 4.6 million people bank online \& no. is expected to grow 16 million by the current year. In 2011-12, non-cash payments comprised 91 per cent of total transactions in terms of value and 48 per cent in terms of volume. Within noncash payments, too, the share of payments through cheques has come down from 85 per cent to nine per cent in value, and 83 per cent to 52 per cent in volume between 2005-06 and 2011-12. But most of the people not aware the risk involved in e- banking .Banking institution should have to aware \& inform the people about the risk.

1. Most of the banking customers are aware of e-banking system as 79 respondents out of total 100 respondents are aware about the e-banking system.

2. Most of the respondents are aware of e-banking system by the television advertisements, from their relatives and friends.

3. Among the 79 respondents only 57 respondents are using e-banking for banking transactions.

4. Among the 57 respondents only 9 respondents are using e-banking since last 2 years. While 18 respondents are using e-banking since last 1 years.

5. E-banking system is very easy to use \& fast it's also gives you 24-hour access to your nationwide accounts. That's the reason most of the respondents attract towards e-banking system.

6. Most of the respondents use e-payment \& electronic fund transfer facility in e-banking system.

7. Among the 57 respondents only 13 respondents are know about the risk involved in e-banking system. Most of the respondents are not aware of the risk.

8. Most of the respondent opt e-banking facility of various banks. 


\section{Limitations}

The response to the questionnaire may be the personal view of the customers and hence do not always reflect the e-banking practices used throughout the country. The present study conducted in Jaipur (Rajasthan) and it may not reflect to other cities.

\section{Conclusions And Recommendations}

The research report is useful to know the customer attitude towards the e-banking system and what types of risk involved in e-banking system. The research report is based on primary data collected. The chisquare statistical test has been used to determine the association between customer and awareness and use of ebanking. In this test, the calculated value is much greater than the critical values of chi-square, the null hypothesis people are not aware and not using e-banking services is rejected. Thus, most of the respondents are aware and using e-banking services.

The following are recommendation of this research:

1. Most of the respondent knows about the e-banking system. But they don't use it. because they don't know about the procedure how to use it, so banking institutions should have to aware the customer about the procedure of utilizing the e-banking system.

2. Most of the banks reluctant to give the information about the use of e-banking. banking institution should have to aware the customers.

3. Some of the services of e-banking are very complicated, banking institution should have to develop user friendly portals for the convenience of the customers.

4. Banking institution should have to aware the customer about the risks involved with e-banking.

5. Customers should have to know about the security risks involved with e-banking and follow the guidelines prescribed by the banks for security.

6. E-banking in India is in budding stage with the high penetration of electronic as a growth driver. Internet banking as tool can be used by the banks towards furthering twin objectives. On one hand banks can optimize its branch operations by doing away with large volumes of routine transactions at individual branches, while one the other hand they can expand their geographical presence by reaching the interior parts of the country either to cut-off from the ambit of banking services. Another important benefit of the concept of internet banking is that it is good for the environment as it cuts down the usage of paper, reduces pollution as people do not have to travel physically and also does not add emissions. It is beneficial for both banks as well as customers. India has a long way to rich the level of e-banking; however it is an easier path to tread now as the security standard and the transaction protocols have been developed and tested. This research paper also gives opportunities to conduct the further development in e-banking and helps to the banking professional

\section{References}

[1]. Gupta P. K. , 'Internet Banking in India: Consumer Concerns and Bank Strategies', Global Journal of Business Research, Vol. 2 (2008)

[2]. Daniel E., 'Provision of electronic banking in UK and republic of Ireland', International Journal of bank marketing Vol 17, No 2 (1999)

[3]. Hawke J. D., 'Internet Banking: Challenges for Banks and Regulators', Institute of Chartered Financial Analysts of India (ICF AI) University Press Publications (2001)

[4]. Chiemeke S.C., The Adoption of Internet Banking in Nigeria: An Empirical Investigation, Journal of Internet Banking and Commerce, 11(3) (2011)

[5]. Duetsche Bank AG Research Retail banking via internet- Banking online boosts and curbs customer loyalty (2011)

[6]. Awamleh, R. and Fernandes C., Internet Banking: An Empirical investigation into the Extent of Adoption by Banks and the Determinants of Customer Satisfaction in the United Arab Emirates, Journal of Internet Banking and Commerce, 10(1) (2012)

[7]. Devi Suma, Electronic Banking-Entry in the Indian Banking Scenario, Banking in the New Millennium, Kanishka Publishers, Distributors, 39 (2009)

[8]. IBA Bulletin - India Banking Association (2013) 